\title{
Günlük Gazetelerde Yayınlanan Eğitimle İlgili Dava Haberlerinin İncelenmesi
}

\section{Examining the Lawsuit News Related to Education in Daily Newspapers}

\author{
Faruk Levent, ${ }^{\mathrm{a}, *}$ Semih Çayak ${ }^{\mathrm{b}}$ \\ ${ }^{a}$ Dr. Öğr. Üyesi, Marmara Üniversitesi, Atatürk Eğitim Fakültesi, Eğitim Bilimleri Bölümü, 34722, İstanbul/Türkiye. \\ ORCID: 0000-0003-3429-6666 \\ ${ }^{\text {b } M a r m a r a ~ U ̈ n i v e r s i t e s i, ~ E g ̆ i t i m ~ B i l i m l e r i ~ E n s t i t u ̈ s u ̈, ~ E g ̆ i t i m ~ Y o ̈ n e t i m i ~ B o ̈ l u ̈ m u ̈, ~ 34722, ~ I ̇ s t a n b u l / T u ̈ r k i y e . ~}$ \\ ORCID: 0000-0003-4360-4288
}

\section{MAKALE BILGİSİ}

\section{Makale Geçmişi:}

Başvuru tarihi: 15 Aralık 2017

Düzeltme tarihi: 22 Şubat 2018

Kabul tarihi: 06 Mart 2018

\section{Anahtar Kelimeler:}

Eğitim Hukuku

Günlük Gazete

Dava Haberleri

\section{ÖZ}

Geniş bir kitleye hizmet sunan eğitim sistemi içerisinde gerek hizmet sunanlardan gerekse hizmet alanlardan kaynaklanan bir takım anlaşmazlıklar ya da istenmeyen durumlar ortaya çıkabilmektedir. $\mathrm{Bu}$ anlaşmazlıklar çözülemeyince bir hukuk devleti olmanın gereği olarak hukuka başvurulmaktadır ve kişiler ya da kurumlar haklarını dava yoluyla aramaya çalışmaktadır. Bu çalışmanın amacı günlük gazetelerde yayınlanmış olan eğitimle ilgili dava haberlerini incelemektir. Araştırmada nitel araştırma yöntemlerinden doküman incelemesi kullanılmıştır. Çalışmada Türkiye'de en çok satılan ve okunan üç gazetede 01 Ocak 2010 - 31 Aralık 2014 tarihleri arasında yayınlanan eğitimle ilgili dava haberleri içerik analizine tabi tutulmuştur. Eğitimle ilgili dava haberleri yapılan içerik analizi neticesinde; kurumları konu alan dava haberleri, bireyleri konu alan dava haberleri ve yapılan uygulamaları konu alan dava haberleri olmak üzere üç tema altında toplanmıştır. Bu çalışmada elde edilen bulgular doğrultusunda günlük gazetelerin eğitimle ilgili dava haberlerinin aktarılmasında çocuk haklarına ve öğretmenlik mesleğinin itibarına yönelik daha dikkatli ve hassas davranması gerektiği söylenebilir.

\section{A B S T R A C T}

In Turkish educational system which provides services to masses of people, there can be disputes or unwanted conditions stemming either from service providers or recipients. When these disputes cannot be resolved, they are referred to the law system as a requisite of living in a state of law and the rights of an individual or an institution are defended through lawsuits. The purpose of this study is to examine the lawsuit news related to education in daily newspapers. Document analysis which is one of the qualitative research methods was used in the study. In the study, the lawsuit news published related to education between 01 January 2010 and 31 December 2014 in the first three of the most widely sold and read newspapers in Turkey were evaluated by content analysis method. Results were presented under three themes: the lawsuits regarding institutions, the lawsuits regarding individuals and the lawsuits regarding practices. The results of the study shows that the daily newspapers need to be more sensitive about children's rights and the reputation of the teaching profession while publishing the lawsuit news related to education.

\section{Giriş}

Duyguların, düşüncelerin, tutumların, tavırların, haber ve mesajların bir kişi, bir grup ya da kurum tarafından karşılıklı olarak iletilmesi anlamına gelen iletişim (Dilmaç, 2004), Latincedeki "communis" kelimesinden türetilmiş olan ve toplumsallaşma anlamına gelen İngilizcedeki “communication" kavramının karşılığı olarak kullanılmaktadır (Dilber, 2014).

İletişim kavramına ilişkin literatürde yapılmış farklı sınıflamalar bulunmaktadır. Kitle iletişimi, bu sınıflamalar içerisinde geniş etki alanına sahip olması nedeniyle gündelik yaşamın sürdürülmesinde önemli bir yere sahiptir (Bayram, 2008). İletilerin hedef kitlelere bazı teknikler yardımıyla tek

\footnotetext{
* Sorumlu yazar/Corresponding author.

e-posta: faruk.levent@marmara.edu.tr
} 
taraflı bilgi aktarımına dayalı olarak gerçekleştiği iletişim türü olan kitle iletişiminin (Mercin, 2010) insanlar arası iletişimi kolaylaştırıp geliştirmede kullandığ olarak; yazılı (kitap, dergi, gazete), sözlü (radyo) ve görselişitsel (televizyon, video, sinema filmi) olmak üzere üç grupta toplanmaktadir (Y1lmaz, 1996).

Günümüzde son derece önemli ve etkili olan kitle iletişim araçlarının birtakım işlevleri mevcuttur. Habercilik, toplumsallaştırma, motivasyon, tartışma-diyalog, eğitim, kültürel açıdan geliştirme, eğlence ve bütünleştirme bu işlevler arasında sayılmaktadır. Bunlardan habercilik işlevi, kitle iletişim araçlarının temel ve en bilinen işlevidir (Savaş, 2004). Bu sebeple kitle iletişim araçlarının en önemli görevlerinden birisi, karmaşık olayları ve haberleri, izleyici veya dinleyici kitlesi tarafından kolayca anlaşılabilir bir hale getirerek sunmak olarak görülmektedir (Gökçe, 1998). Bu görevi gerçekleştirirken kitle iletişim araçları insanların ilgisini çeken haberlere yer vererek (Rivers, 1982) izleyiciler, okuyucular ve tüm toplum için bir çeşit kamuoyu oluşturma görevini üstlenmektedir (Turam, 1994).

Medya; toplumları yönlendirmede, kültürü şekillendirmede ve bunun gelecek nesillere aktarılmasında büyük öneme sahiptir (Akdoğan, 1994). Bu nedenle günümüz modern bilgi toplumu, medya ile desteklenen iletişim süreçlerini gerektirmektedir (İlbuğa, 2010). Nitekim yapılan yayınlarla medya; düşünceleri etkileyebilmekte, duyguları yönlendirebilmekte ve davranışlarda değişikliğe yol açabilmektedir (Ertürk, 2011; Kara, 2011). Bu açıdan kitle iletişimini vazgeçilmez kılan temel özelliklerden birisi bir anda çok sayıda insana, mesaj ulaştırma imkânı vermesidir. Çağımız iletişim teknolojisinin olanakları sayesinde bu iletim hızı ve ulaşılabilen insan sayısı giderek artmaktadır. Milyonlarca insan tarafından okunan gazeteler değişik bölümleri veya türleri ile her düzeyden ve meslekten farklı merakları olan okuyucu gruplarına hitap ederek kamuoyunda büyük etki oluşturmaktadır (Yılmaz, 1996). Bunun yanında gazeteler her ne kadar haber verme işlevi ile ön plana çıksalar da okuyucuları tarafindan eğlenme, sosyal uyum, boş zamanı değerlendirme gibi değişik amaçlarla da kullanılabilmektedir (Bayram, 2008). Özellikle son dönemde artan ve gelişen iletişim araçları ile insanlar akıllı telefonları, tablet bilgisayarları vb. birçok farklı yolu kullanarak istedikleri her an haberleri günlük gazetelerin internet sayfalarından takip edebilmektedir. Dolayısıyla gerek ulusal düzeyde gerekse uluslararası düzeyde meydana gelen olaylar, yazılı medya araçları vasıtasıyla konu hakkında çok kısa sürede kamuoyu oluşturabilmektedir. Bu bağlamda medya; çoğunlukla yasama, yürütme ve yargıdan sonra dördüncü bir güç olarak görülmektedir (Keane, 2010). Ancak medyanın bu işlevini her zaman tam olarak yerine getirip getirmediği tartışılan bir konudur (Pavlink, 2013).

Medya ile eğitim arasında çok boyutlu bir ilişki bulunmaktadır. Eğitim ve medya, açık sistem yaklaşımına göre işleyen birer sosyal kurum olarak karşılıklı etkileşim içindedir. Bu bakımından eğitim, vatandaşların eğitimi ile medyanın daha nicelikli ve nitelikli bir izleyici kitlesi oluşmasına katkıda bulunur. Bununla birlikte medyanın hem örgün hem de yaygın eğitimde bir eğitsel araç olarak rol üstlendiği söylenebilir. Gelişen kitle iletişiminin ekonomiklik, çok yönlülük, tercih imkânları, farklı duyu organlarına hitap gibi özelliklerinden dolayı etkili bir eğitim aracı olarak eğitimde daha çok kullanılma eğilimi söz konusudur. Yazılı ve görsel kitle iletişim araçlarından öğretim programlarında da doğrudan yararlanma eğilimleri Türkiye'de çokça dile getirilmekte ve uygulamaya geçirilmeye çalışılmaktadır (Erdoğan, 2002).

Günümüz okulları kompleks bir yasal çevrede faaliyette bulunmaktadır ve oldukça geniş yasal konular yelpazesi öğretmenlerin, öğrencilerin ve velilerin yaşamlarını etkilemektedir (Fischer vd., 1995'den aktaran: Gullat ve Tollett, 1997). Bu açıdan eğitim sisteminin amaçlarının gerçekleşmesi, eğitimin önündeki maddî ve manevî engellerin ortadan kaldırılmasında hukukun yardımına ihtiyaç duymaktadır. Evrensel hukukta bir kamu hizmeti olarak yer alan eğitim hizmetinin yerine getirilmesi devletin asli görevi olarak görülmektedir ve devlet bu hizmeti yerine getirirken bir hukuk düzenine dayanmak zorundadır (Okçu, 2007). Hukuk sistemi içinde oldukça yeni bir hukuk dalı olarak ortaya çıkan eğitim hukuku, eğitim örgütlerinin işleyişini düzenlemeyi amaçlayan hukuk kurallarının eleştirilmesi, değerlendirilmesi, yorumlanması ve tartışılması gibi yollarla bu alandaki kuralların daha iyiye ulaşmasına ve gelişmesine yardımcı olur (Kepenekçi ve Taşkın, 2017).

Öğrenciler, veliler ve öğretmenler ile birlikte çok büyük bir paydaş kitlesine sahip olan eğitim-öğretim hizmetleri sürecinde kişiler arasında zaman zaman birtakım istenmeyen olumsuz durumlar, hukuka aykırı olaylar yaşanabilmektedir. $\mathrm{Bu}$ durum her alanda olduğu gibi eğitim-öğretim süreci içerisinde de hukuki yollara başvurmayı gerekli kılmaktadır. Bireye olumlu tutum ve davranışlar kazandırmak gibi amaçları olan böyle bir süreç içerisinde meydana gelen bu tip durumlar medyada haber olarak yer alabilmektedir.

Eğitimle ilgili haberler, ilgilendirdiği kitle ve oluşturduğu etki bakımından büyük öneme sahiptir. Özellikle 18 yaşına kadar her insanın çocuk olduğu ve toplum içerisinde eğitim hizmeti alan bireylerin çoğunluğunun çocukların oluşturduğu göz önüne alınırsa eğitimle ilgili haberlerin farklı açılardan incelenmesi gerektiği söylenebilir. Bu çalışmanın amacı, 1 Ocak 2010 - 31 Aralık 2014 tarihleri arasında Türkiye'de günlük gazetelere yansıyan eğitimle ilgili dava haberlerini incelemektir. Araştırmada belirtilen tarih aralığının seçilmesinin sebebi, araştırma kapsamında incelenen üç gazetenin her birinin belirtilen tarihler arasındaki arşivlerine ulaşma imkânın daha kolay olmasıdır. $\mathrm{Bu}$ amaç doğrultusunda bu çalışmada eğitimle ilgili dava haberlerinin günlük gazetelerde ne oranda yer aldığı ve bu haberlerin nasıl ele alındığı incelenmiştir.

\section{Yöntem}

\subsection{Araştırmanın Deseni}

$\mathrm{Bu}$ çalışmada günlük gazetelerdeki eğitimle ilgili mahkemelere yansıyan dava haberleri incelediğinden araştırmanın deseni durum çalışmasıdır. Bu araştırmada nitel araştırma yöntemlerinden doküman incelemesi kullanılmıştır. Doküman incelemesinde çalışılacak konular ile ilgili olarak yazılı ve basılı belgelerin analizini içerir (Cohen vd., 2000). Doküman incelemesi, araştırılması hedeflenen olgu ya da olgularla ilgili yazılı materyallerin analizi yapılmaktadır. Doküman incelemesinin en önemli özelliği ise hâlihazırda basılı ve yazılı olan verinin değişmez 
olması nedeniyle istenilen her anda veriye geri dönüp inceleme imkânı vermesidir (Yıldırım ve Şimşek, 2013).

\subsection{Verilerin Toplanması ve Analizi}

Konu ile ilgili olarak Bilgi Edinme Kanunu çerçevesinde Aralık 2014 itibariyle Basın İlan Kurumu'ndan elde edilen veriler doğrultusunda Türkiye'de günlük tirajı en yüksek ilk üç ulusal gazetenin 1 Ocak 2010 - 31 Aralık 2014 tarihleri arasında internet ortamındaki haberleri incelenmiştir. Araştırma kapsamında incelenen üç gazetede, beş yıllık süre zarfında yayınlanmış bütün haberler taranmış ve eğitimle ilgili mahkemelere yansıyan 361 dava haberi belirlenmiştir. Tespit edilen bu haberler, içerik analizi yöntemi ile incelenerek benzer haberler belirli temalar oluşturularak gruplandırılmıştır.

\section{Bulgular}

Araştırma kapsamında incelenen gazetelerde yayınlanan eğitimle ilgili dava haberlerinin sayısal dağılımı Tablo 1'de verilmiştir.

Tablo 1. Gazetelere Göre Eğitimle İlgili Dava Haberlerinin Sayısal Dağılımı

\begin{tabular}{cc}
\hline Gazete & $\begin{array}{c}\text { Eğitimle İlgili Gazetelere Yansıyan Davalara } \\
\text { İlişkin Haber Sayısı (f) }\end{array}$ \\
\hline A & 159 \\
B & 135 \\
C & 67 \\
Toplam & 361 \\
\hline
\end{tabular}

Tablo 1'de görüldüğü üzere incelenen gazetelerde, eğitimle ilgili mahkemelere yansıyan 361 dava haberinin 159'u A Gazetesi'nde, 135'i B Gazetesi'nde ve 67'si C Gazetesi'nde yayınlanmıştır.

Araştırma kapsamında incelenen gazetelerdeki eğitimle ilgili dava haberleri yapılan içerik analizi neticesinde; kurumları konu alan dava haberleri, bireyleri konu alan dava haberleri ve yapılan uygulamaları konu alan dava haberleri olmak üzere üç tema altında toplanmıştır (Şekil 1).

Şekil 1. Gazetelerdeki Eğitimle İlgili Dava Haberlerine Ait Temalar

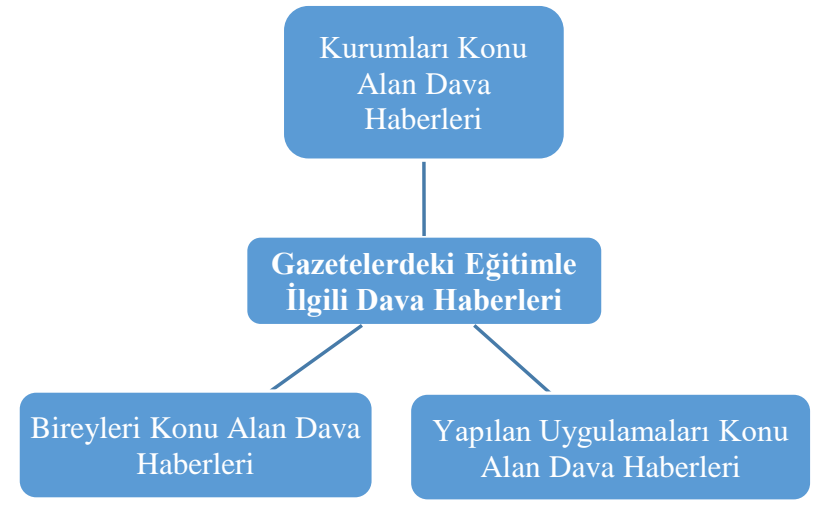

Kurumları konu alan dava haberleri temasına ait alt temalar ve bu alt temalarla ilgili haber sayıları Tablo 2'de verilmiştir.

Tablo 2'de görüldüğü üzere incelenen gazetelerdeki eğitimle ilgili mahkemelere yansıyan dava haberlerinin 10 farklı kurumla ilgili olduğu belirlenmiştir. Bu haberlerin 221 'i
Milli Eğitim Bakanlığı ile 28'i il/ilçe milli eğitim müdürlükleriyle, 13'ü YÖK ile 10'u özel öğretim kurumlarıyla, 5'i sivil toplum örgütleri/ sendikalarla, 4'ü üniversitelerle, 4'ü ÖSYM ile 3'ü askeri okullarla, 2'si siyasi partilerle ve 1 '’ üstün yetenekli öğrencilere yönelik kurumlarla ilgilidir.

Tablo 2. Kurumları Konu Alan Dava Haberleri Temasına Ait Alt Temalar

\begin{tabular}{|c|c|c|}
\hline Tema & Alt Temalar & $\begin{array}{c}\text { İlgili } \\
\text { Haber } \\
\text { Sayıs1 (f) }\end{array}$ \\
\hline \multirow{11}{*}{$\begin{array}{l}\text { Kurumları } \\
\text { konu alan } \\
\text { dava } \\
\text { haberleri }\end{array}$} & $\begin{array}{l}\text { Milli Ĕ̆gitim Bakanlığı (MEB) ile } \\
\text { ilgili dava haberleri }\end{array}$ & 221 \\
\hline & $\begin{array}{l}\text { İl/ilçe milli eğitim müdürlükleri ile } \\
\text { ilgili dava haberleri }\end{array}$ & 28 \\
\hline & YÖK ile ilgili dava haberleri & 13 \\
\hline & $\begin{array}{l}\text { Özel öğretim kurumları (özel } \\
\text { okullar, dershaneler) ile ilgili dava } \\
\text { haberleri }\end{array}$ & 11 \\
\hline & $\begin{array}{l}\text { Sivil Toplum Örgütleri/Sendikalar } \\
\text { ile ilgili dava haberleri }\end{array}$ & 5 \\
\hline & ÖSYM ile ilgili dava haberleri & 4 \\
\hline & $\begin{array}{l}\text { Üniversiteler ile ilgili dava } \\
\text { haberleri }\end{array}$ & 4 \\
\hline & $\begin{array}{l}\text { Askeri okullar ile ilgili dava } \\
\text { haberleri }\end{array}$ & 3 \\
\hline & $\begin{array}{l}\text { Siyasi partiler ile ilgili dava } \\
\text { haberleri }\end{array}$ & 2 \\
\hline & $\begin{array}{l}\text { Üstün yetenekli öğrencilere yönelik } \\
\text { okullar ile ilgili dava haberleri }\end{array}$ & 1 \\
\hline & Toplam & 292 \\
\hline
\end{tabular}

Bireyleri konu alan dava haberleri temasına ait alt temalar ve bu alt temalarla ilgili haber sayıları Tablo 3 'te verilmiştir.

Tablo 3. Bireyleri Konu Alan Dava Haberleri Temasina Ait Alt Temalar

\begin{tabular}{llc}
\hline Tema & \multicolumn{1}{c}{ Alt Temalar } & $\begin{array}{c}\text { İlgili } \\
\text { Haber } \\
\text { Saylsı (f) }\end{array}$ \\
\hline & $\begin{array}{l}\text { Öğretmenlerin hakları ile ilgili dava } \\
\text { haberleri } \\
\text { Cinsel istismar, fiziksel ve sözlü taciz } \\
\text { ile ilgili dava haberleri } \\
\text { Hakaret davaları ile ilgili dava } \\
\text { haberleri }\end{array}$ & 24 \\
& $\begin{array}{l}\text { Yolsuzluk ve görevi kötüye kullanma } \\
\text { ile ilgili dava haberleri } \\
\text { Bireyleri } \\
\text { konu alan } \\
\text { dava } \\
\text { haberleri }\end{array}$ & $\begin{array}{l}\text { Okullarda meydana gelen şiddet } \\
\text { olayları ile ilgili dava haberleri }\end{array}$ \\
$\begin{array}{l}\text { Öğretmenlerin özel hayatıyla ilgili } \\
\text { dava haberleri }\end{array}$ & 19 \\
$\begin{array}{l}\text { Öğretmenlerin yaptıkları çalışmalara } \\
\text { ve konuşmalara yönelik dava } \\
\text { haberleri }\end{array}$ & 3 \\
$\begin{array}{l}\text { Üstün yetenekli öğrencilerle ilgili } \\
\text { dava haberleri } \\
\text { Toplam }\end{array}$ & 3 \\
\hline
\end{tabular}

Tablo 3'te görüldüğü üzere bireyleri konu alan dava haberleri teması altındaki haberlerin; 24'ü öğretmenlerin hakları ile ilgili dava haberleri, 23'ü cinsel, fiziksel ve sözlü taciz ile ilgili dava haberleri, 11 'i hakaret davaları, yolsuzluk 
ve görevi kötüye kullanma ile ilgili dava haberleri, 11'i okullarda meydana gelen şiddet olayları ile ilgili dava haberleri, 7'si öğretmenlerin özel hayatı ile ilgili dava haberleri, 3'ü öğretmenlerin yaptıkları çalışmalara ve konuşmalara yönelik dava haberleri ve 3 'ü üstün yetenekli öğrencilerle ilgili dava haberleri olmak üzere sekiz farklı alt tema altında toplanmıştır. Yapılan uygulamaları konu alan dava haberleri temasina ait alt temalar ve bu alt temalarla ilgili haber sayıları Tablo 4'te verilmiştir.

Tablo 4. Yapılan Uygulamaları Konu Alan Dava Haberleri Temasina Ait Alt Temalar

\begin{tabular}{llc}
\hline \multicolumn{1}{c}{ Tema } & \multicolumn{1}{c}{ Alt Temalar } & $\begin{array}{c}\text { İlgili Haber } \\
\text { Sayıs1 (f) }\end{array}$ \\
\hline & $\begin{array}{l}\text { Yasal düzenlemelere ve mahkeme } \\
\text { kararlarına yönelik dava haberleri }\end{array}$ & 65 \\
& $\begin{array}{l}\text { Yönetici ve öğretmen atamaları ile } \\
\text { ilgili dava haberleri }\end{array}$ & 59 \\
Yapılan & Sinavlarla ilgili dava haberleri & 53 \\
uygulamaları & Meydana gelen okul ve servis kaza & 35 \\
konu alan & haberleri ile okullarda karşlaşlan & \\
dava & tehlikeli durumlar ile ilgi dava & \\
haberleri & haberleri & \\
& Başörtüsü ile ilgili dava haberleri & 12 \\
& Katsayı ile ilgili dava haberleri & 9 \\
& Derslerle ilgili dava haberleri & 8 \\
& Toplam & 241 \\
\hline
\end{tabular}

Tablo 4'te de görüldüğü üzere yapılan uygulamaları konu alan dava haberleri 65'i yasal düzenlemelere ve mahkeme kararlarına yönelik dava haberleri, 59'u yönetici ve öğretmen atamaları ile ilgili dava haberleri, 53'ü sınavlarla ilgili dava haberleri, 12'si başörtüsü ile ilgili dava haberleri, 9'u katsayı ile ilgili dava haberleri ve 8 'i derslerle ilgili dava haberleri olmak üzere altı alt tema altında toplanmıştır.

\section{Sonuç ve Değerlendirme}

Günlük gazetelerde, çok geniş bir kitleyi ilgilendiren eğitim camiası ile ilgili farklı nedenlerle mahkemelere yansımış dava haberleri ile karşılaşılabilmektedir. Değişik kurum ve kişilerle ilgili olan bu dava haberleri eğitim sistemindeki sorunlara bir $1 s ̧ \mathrm{k}$ tutabilmektedir. Zira eğitim alanında görülen aksaklıkların ve yanlışlıkların ileride tekrarlanmaması için ve gerekli önlemlerin alınması için bu davalar, ilgili kişilere ve yetkililere birer ipucu niteliğindedir. Medyanın önemli bir organı olan gazeteler topluma doğru ve tarafsız haberlerin ulaştırılmasında büyük etkiye sahiptir. Bu bağlamda gazetelerde eğitimle ilgili mahkemelere yansıyan dava haberlerinin yer alması, toplumun ilgili konularda bilinçlenmesine ve kamuoyu oluşturabilmesine yardımcı olmaktadır.

Araştırma kapsamında incelenen üç gazetede 01 Ocak 201031 Aralık 2014 tarihleri arasında eğitimle ilgili mahkemelere yansıyan 361 dava haberi tespit edilmiştir. Yapılan içerik analizi neticesinde bu haberler kurumları konu alan dava haberleri, bireyleri konu alan dava haberleri ve yapılan uygulamaları konu alan dava haberleri olmak üzere üç tema altında ele alınmıştır.

Kurumları konu alan dava haberleri teması altında incelenen haberler içinde Milli Eğitim Bakanlığ 221 dava haberi ile en üst sırada yer almaktadır. Bunun nedeni olarak ülkede en büyük kitleye hizmet veren bir bakanlık olması ve personel sayısının çok fazla olması gibi etkenlerin etkili olduğu düşünülmektedir. Buna bağlı olarak böylesine büyük bir sistemde yapilan uygulamalar ve alınan kararlar bazen hukuken uygunsuzluk yaratabilmekte ya da farklı bir takım olaylar nedeniyle Bakanlık davalı konumunda olabilmektedir. Örneğin İzmir Konak ilçesinde bulunan Zafer İlköğretim Okulu'nun 2007 yılında düzenlediği Kapadokya gezisine gidilirken Aksaray'da meydana gelen trafik kazasında ölen öğrenci ve veli yakınları, Milli Eğitim Bakanlığı (MEB) ve İzmir Valiliğine karşı açtıkları 14 tazminat davasının sonuçlanması ile ilgili haber, C Gazetesi'nin 09.04.2010 tarihli “Kapadokya Faciasına 1 Milyon TL Tazminat” başlığıyla okuyucuya duyurulmuştur. $\mathrm{Bu}$ haberde; Kapadokya gezisine giderken, 46 kişilik otobüse 64 kişinin binmesi ve geçirdikleri trafik kazası sonucu çoğunluğu öğrenci olmak üzere 33 kişinin hayatını kaybetmesi neticesinde yürütülen dava sonucundan bahsedilmektedir. Özellikle televizyonda yayınlanan haberlerde çocukların zaman zaman bu tarz kaza ve trajik olaylarla karşılaştıkları görülebilmektedir. Gencel Bek (2011) de Ocak-Ekim 2005 tarihleri arasında yaptığ araştırmada gazetelerde yayınlanan haberlerde çocuklarla ilgili şu konularda haberler yapıldığını tespit etmiştir: Suç/şiddet mağduru olarak çocuklar (\%24), afet, kaza, trajedi haberlerinde çocuklar $(\% 15,8)$, kimsesiz çocuklar (\%6), ünlülerin çocukları ile ilgili haberler $(\% 5,1)$ ve çocuk işçiliği $(\% 0,5)$ 'dir. Bu konuda T.C. İçişleri Bakanlığı tarafından çıkarılan ve 25.10.2017 tarihinde Resmi Gazete'de yayınlanan 30221 sayılı Okul Servis Araçları Yönetmeliği’nde ve T.C. Milli Eğitim Bakanlığı tarafından çıkarılan ve 28.08.2007 tarihinde Resmi Gazete'de yayınlanan 26627 sayılı Okul Servis Araçları Hizmet Yönetmeliği’nde belirtilen yasal düzenlemelere ilgili kişi ve kurumların uyması yukarıdaki haberde geçen üzücü durumların bir daha yaşanmaması açısından büyük önem arz etmektedir.

Ayvaz, Tümerdem, Özel, Önal ve Erdoğan (2009) çocukların okul taşıtlarında, okula giriş ve çıkışlarda, siniflarda, koridorlarda, oyun ve spor alanlarında, laboratuvar veya atölye gibi yerlerde çok sayıda tehlikeyle karşı karşıya olduğunu ifade etmiştir. Erkal ve Yertutan (2012) da çocukların okulda kaza geçirme durumlarına ilişkin yaptıkları araştırmada, katılımcı ailelerin çocuklarının \%9,5'inin çocuklarının son üç yıl içerisinde okulda herhangi bir tür kaza geçirdiklerini ortaya koymuştur. Bu bağlamda Dönmez'in (2001) de belirttiği gibi öğrencilerin kendilerinden, diğer öğrencilerden ya da çevreden kaynaklanan şiddet, saldırganlık, alkol, uyuşturucu, cinsel taciz gibi istenmeyen davranışlara karşı korunmaları, trafik, yangın, sel, deprem gibi olaylara karşı can güvenliklerinin en üst düzeyde sağlanması hususunun okulun ve dolayısıyla okul yöneticilerinin en önemli görevlerinden biri olduğu unutulmamalı ve bu konularda gerekli önlemler alınmalıdır.

Bireyleri konu alan dava haberleri teması altında incelenen haberler içinde "cinsel, fiziksel ve sözel taciz ile ilgili dava haberleri" 23 haber ile ikinci sırada yer almaktadır. Bu alt temalar içerisinde en dikkat çeken haberlerden birisi B Gazetesi'nin 19.05.2014 tarihli “Öğrenci Döven Öğretmene 5 Yıl Hapis Talebi” başlıklı haberdir. Bu haberde, öğrencilerine fiziksel şiddet uyguladığı iddia edilen bir ilkokul öğretmenine ilişkin davadan bahsedilmektedir. Bu davanın konusu haberde şöyle aktarılmıştır: 
"Muratpaşa ilçesindeki Fatmagül Özpınar İlköğretim Okulu 2'nci sınıf öğretmeni 61 yaşındaki Fikriye U. hakkında bazı veliler, geçen yıl Ekim ayında çocuklarının "Öğretmenimiz bizi dövüyor, kalemlerimizi kırıyor, incitici sözler söylüyor" sözleri üzerine Milli Eğitim İl Müdürlüğü'ne şikayet dilekçesi verdi. Milli Eğitim müfettişleri, soruşturma sonucunda Fikriye U.'nun başka bir okulda görevlendirilmesine karar verdi ve hakkında savcılığa suç duyurusunda bulundu. Suç duyurusu sonrası Fikriye U. hakkında Antalya 9'uncu Sulh Ceza Mahkemesi'nde açılan davanın görülmesine başlandı. Pedagog bilirkişi Fatih Fidan eşliğinde ifade veren öğrencilerden O.K.G. şöyle dedi: "Öğretmenimiz bizi tahtaya çıkartıp, kafamizl tahtaya vururdu. Kulağımızdan tutup sıraya vurmuştur. Elimizi mıncıklamış, kalemimizi kırıp yüzümüze atmıştır. Daha önce korktuğum için anneme, babama anlatamiyordum. Daha sonra söylemeye karar verdim. Benim kilom biraz fazla. Bana, 'boşboğaz, açgözlü' gibi sözler söylüyordu.".

Öğretmeninden korktuğu için okulunu değiştirdiğini öne süren A.E.E. ise "Bana vurmadı ama arkadaşım O.K.G.'ye çeşitli zamanlarda vurduğu için kendisinden çok korkuyordum. Bana vurmadı ama şu anda hatırlamadığım incitici sözler söyledi. Ben bunları anneme söylemiştim” dedi.

Öğretmen Fikriye U. ise hakkındaki suçlamaları kabul etmedi. Fikriye U. duruşmada kendini şöyle savundu: "Ben kimseye kalem firlatmadım. Sadece sinıfta ucu siyah olan kurşun kalemlerin să̆lı̆̆a zararlı olduğu için kullanılmasını yasaklamıştım. Ancak kimseye firlatmadım. Ayrica okulumuzda kameralar var. Ben ögrencilerimle her gün bir anne gibi, hatta arkadaş gibi ilgilenmekteyim. Suçsuzum".

Tarih boyunca yetişkinler tarafindan kontrol edilen medyada, çocukların çoğunlukla bir özne olmaktan çok nesne olarak sunulduğuna rastlanmaktadır (Kaziaj, 2016). Nitekim yukarıda ele alınan B Gazetesi'nin haberinde olduğu gibi bu araștırmada incelenen bazı haberlerde öğrencilerin kimliklerini ortaya çıkarabilecek şekilde okuyucuyla paylaşıldığı görülmektedir. Ancak bu durumun çocuk haklarına aykırı bir durum olduğu unutulmamalıdır. Çocuk hakları açısından en temel yasal kaynak Birleşmiş Milletler Çocuk Hakları Sözleşmesi'dir. Birleşmiş Milletler Genel Kurulu tarafindan 20 Kasım 1989 tarihinde benimsenen ve 2 Eylül 1990 tarihinde yürürlüğe girmis olan bu sözleşme Türkiye'nin de aralarında bulunduğu 142 ülke tarafından imzalanmıştır (Levent, 2011; Gören, 2012). Türkiye'de 27 Ocak 1995 tarihinde Resmi Gazete'de yayınlanarak bir iç hukuk kuralı haline gelmiş olan Çocuk Hakları Sözleșmesi'nin en önemli maddelerinden biri olarak görülen 3. Maddesi, çocukları ilgilendiren tüm faaliyetlerde toplumun tüm kurumlarının çocuğun öncelikle yüksek yararını dikkate alması gerektiğini belirtmektedir (Avcı, 2011). Modern devletin çocuğa karşı görevi bedensel, duygusal, zihinsel ve ahlâkî güvenliğine, diğer bir deyişle “çocuğun yüksek yararına" özen göstermek bakımından yalnızca anne-babayı desteklemek ve denetlemek değildir. Devlet aynı zamanda çocukların yetenekleri doğrultusunda gelişimlerini güvence altına almak, onların ekonomik ve sosyal refahını da sağlamak zorundadır. Çocuğun yararının önceliği ilkesi, özellikle çocuğun özel olarak korunmasını gerektiren durumlarda pratik önem kazanır (Akyüz, 2012). Buna bağlı olarak medya kuruluşlarının çocuklara yönelik haberleri sunarken çocuk mağdurların kimliklerini açığa vurmaması gerekmektedir (Şirin vd., 2013).

Bir toplumda çocuklar kötü muamele görüyorsa, ihmal ve istismar ediliyorsa o toplumun kültürü geri kalmış bir kültür olarak nitelendirilebilmektedir. Buna karşın, çocuklara değer veren ve onlara sağlıklı gelişme olanakları sunabilen toplumların ileri bir kültür düzeyinde oldukları söylenebilir (Akyüz, 2012). Öte yandan Kuş, Karatekin, Öztürk ve Elvan (2016) yaptıkları araştırmada Türk medyasında çocukların genelde olumsuz haberlerle anıldığını bu durumun da çocukların yaşam, gelişim, korunma ve katılım haklarını hem ulusal hem de uluslararası düzeyde ihlale yol açtığını belirtmektedir. Lansdown ve Karkara'nın (2006) da ifade ettiği gibi dünya genelinde çocukların karşı karşıya kaldıkları şiddetin etkisinin, zararının ve yaygınlığının büyüklüğü oldukça fazladır. $\mathrm{Bu}$ noktada gazetelerin, çocuklarla ilgili haber hazırlarken haberin içeriğinde çocukları olumsuz etkileyebilecek unsurların yer almasını engellemek için gereken özeni göstermeleri gerekmektedir (Levent, 2013). Zira çocuk hakları ve gazetecilik ilkeleri konusunda UNICEF (2007) çocuklarla ilgili haberlerde, çocukların kimliğinin tespitini sağlayacak bilgilerin verilmemesi gerektiğini vurgulamaktadır. $\mathrm{Bu}$ nedenle "Öğrenci Döven Öğretmene 5 Yıl Hapis Talebi” başlıklı haberde bulunan ifadeler bu çalışmada aynen aktarılmış ancak kişilerin ad ve soyadları "üç nokta işareti" ile gösterilmiştir. Ancak B Gazetesi'nin bu haberinde; öğrencilerin ad ve soyadlarının ilk harfleri kullanılırken öğretmenin adının tamamı, soyadının ise ilk harfi yazılmıştır. Gazetecilerin, bilginin toplanması ve yayınlanması sürecinde çocuklara zarar vermeden onları adil bir şekilde temsil etme sorumlulukları vardır (UNICEF, 2007). Oysa bu haberde, ilkokul ikinci sınıf öğrencilerinin maruz kaldığı iddia edilen fiziksel şiddet olaylarının ayrıntılı bir şekilde anlatılması ve öğretmenin söylediği iddia edilen sözlerin okuyucularla açıkça paylaşılması oldukça düşündürücü olup aynı zamanda bu haberde Çocuk Hakları Bilgi Ağı CRIN (Child Rights International Network)'in belirlediği, çocuklarla ilgili haber yaparken başvurulacak etik ilkelerden biri olan “... çocuğun travmatik olaylara ilişkin acı ve üzüntüsünü tekrar canlandıracak soru, tavır ve yorumlardan kaçının. ” maddesinin ihlal edildiği görülmektedir.

Ayrıca eğitim camiası içinde cinsel istismar, fiziksel şiddet, hakaret davalarına ilişkin haberlerin gazetelerde çok fazla yer alması dikkat çekicidir. Bununla birlikte yazılı medyada toplumu aydınlatan ve gelecek nesilleri yetiştiren kişiler olan eğitimcilerin bu tarz haberlerle ön plana çıkarılmaması gerekmektedir. Çünkü kitle iletişim araçları, insanın dünya görüşünü, tutum ve davranışlarını etkilemekte ve diğer bildirimler ile insanların algılarını önemli ölçüde değiştirmektedir (Dilber, 2014). İlbuğa'nın (2010) da belirttiği gibi medyadaki gelişmeler ve toplumsal sonuçları öğretmenlik mesleği üzerinde uzun süredir bir baskı oluşturmaktadır. Bu bağlamda medyanın ve özellikle de gazetelerin bu tip haberleri sunarken, basın etiği çerçevesinde, haber yapılan kişilerin de konumlarını dikkate alarak haberi tüm meslek çalışanlarına mâl etmeden ve gerekli hassasiyeti göstererek vermesi büyük önem arz etmektedir. 
Yapılan uygulamaları konu alan dava haberleri içinde, 65 haberle "yapılan yasal düzenlemeler ve mahkeme kararlarına yönelik dava haberleri” öne çıkmaktadır. Yapılan yasal düzenlemelere ve mahkeme kararlarına yönelik dava haberlerinin diğer dava haberleri içinde sayısal olarak çok fazla olması, yasal düzenlemelerin ve mahkeme kararlarının kişiler üzerinde olumsuz bir durum oluşturması başka bir ifadeyle mağduriyet yaratması nedeniyle kişilerin haklarını arama yolu olarak yargıya başvurduklarını göstermektedir. Zira yasaların ve yönetmeliklerin mevcut durumda var olan sorunları çözmek, bireylere ya da topluma faydalı ek düzenlemeler getirmek için yapıldığı düşünüldüğünde eğitimle ilgili yapılan yasal düzenlemelere ve mahkeme kararlarına yönelik bu kadar fazla itirazın olması politika yapıcılar ve kanun uygulayıcılara bir uyarı niteliğindedir.

Okulu yöneten kişiler olarak okul müdürleri, yasa ve yönetmeliklerin kendilerine vermiş olduğu yetkiye bağlı olarak okula her türlü girdilerin sağlanmasından ve bunların okul amaçlarını gerçekleştirme yönünde kullanılmasından sorumlu olan kişilerdir. Bu açıdan okul müdürleri; okulun insan kaynağının ve diğer kaynakların sağlanması ve uygun şekilde kullanılması, eğitim-öğretimle ilgili tüm etkinliklerin planlanıp uygulanması, denetlenmesi, değerlendirilmesi, okulda iletişim ve eşgüdümün sağlanması, ortaya çıkan sorunların çözümü kapsamında yer alan görevlerini yerine getirmek durumundadır (Özden, 2005). Öte yandan okulun en stratejik öğelerinden biri olan öğretmenlerin üstlendikleri rol ve sorumluluklar da büyük önem taşımaktadır (Bursalığlu, 1998). Eğitimde böylesine önemli bir pozisyonda bulunan yönetici ve öğretmen atamalarıyla ilgili dava haberlerinin sayının $(\mathrm{f}=59)$ çok fazla olması düşündürücüdür. Bunun yanında gerek yönetici gerekse öğretmen atamalarına ilişkin bu kadar çok dava açılmasının, personel atamalarında ve görevlendirmeler yapılırken yaşanan mağduriyetlerden kaynaklandığı söylenebilir. Zira hem atama bekleyen öğretmenlerin durumu, hem de değişik nedenlerle istediği yere atanamayan ve bunun sonucunda da işine mutsuz bir şekilde giden öğretmenlerin var olması eğitim camiası adına ciddi bir sorun olarak değerlendirilebilir. Bu bağlamda atama konusu ile ilgili dava haberlerinin gazetelerde haber olması hem konu ile ilgili toplumsal bir bilinç oluşturabilmek hem de ilgili mercilere eğitimcilerin sesini duyurabilmek açısından faydalı olduğu düşünülebilir.

\section{Kaynakça}

Akdoğan, Y. (1994). Temel özellikleri açısından gazetetelevizyon etkileşimi ve gazete-televizyon etkileşimini yansitan uygulama. Yüksek Lisans Tezi. Eskişehir: Anadolu Üniversitesi.

Akyüz, E. (2012). Çocuk hukuku: Çocukların hakları ve korunması, Ankara: PegemA Yayınları.

Avcı, A. (2011). Çocuk haklarının medya boyutusözleşmeler ve yasal düzenlemeler. İçinde: Çocuk haklarl ve medya el kitabl, (ss. 89-105). İstanbul: Çocuk Vakfi Yayınları.

Ayvaz, Ö., Tümerdem, Y., Özel, S., Önal, E., \& Erdoğan, A. (2003). Ortaöğretim öğrencilerinde kazalar. İçinde: 8 . Halk Sağlığ Günleri Bildiri Özetleri Kitabı, (ss.79-80), Sivas.
Bayram, F. (2008). Gazete okurlarının okuma motivasyonları ve doyumları üzerine bir kullanımlar ve doyumlar araştırması. Anadolu Üniversitesi Sosyal Bilimleri Dergisi, 8(1), 321-336.

Bursalığlu, Z. (1998). Okul yönetiminde yeni yapı ve davranış. Ankara: PegemA Yayıncılık.

Cohen, L., Manion, L., \& Morrison, K. (2000). Action research, Research Methods in Education, 5, 226-244.

Dilber, F. (2014). Kitle iletişim araçları ve suç olgusu. KMÜ Sosyal ve Ekonomik Araştırmalar Dergisi, 16(Özel Sayı 1), 60-66,

Dilmaç, B. (2004). "Sınıfta etkili iletişim". İçinde: Sınıf yönetimi, (Ed: Musa Gürsel, Hakan Sarı \& Bülent Dilmaç). Konya: Eğitim Yayıncılık.

Dönmez, B. (2001). Okul güvenliği sorunu ve okul yöneticisinin rolü. Kuram ve Uygulamada Egitim Yönetimi Dergisi, 7(1), 63-74.

Erdoğan, İ. (2002). Eğitimde yeni yönelimler. İçinde: Ögretmenlik mesleğine giriş içinde (Ed. Ö. Demirel \& Z. Kaya). Ankara: PegemA Yayıncılık.

Ertürk, Y. D. (2011). Çocukluk çağı gelişim dönemlerine göre medya kullanımı. İçinde: Çocuk hakları ve medya el kitabı. İstanbul: Çocuk Vakfı Yayınları.

Gencel Bek, M. (2011). Medyada çocuk hakları ve etik ilkeler. İçinde: Çocuk haklarl ve medya el kitabı, (Haz. Mustafa Ruhi Şirin). İstanbul: Çocuk Vakfı Yayınları.

Gökçe, O. (1998). Illetişim bilimine giriş: insanlar arası ilişkilerin sosyolojik bir analizi. Ankara: Turhan Kitabevi.

Gören, Z. (2012). Çocukların temel haklarının anayasal garantisi. Istanbul Ticaret Üniversitesi Sosyal Bilimler Dergisi, 11(22), 45-105.

Gullatt, D. E., \& Tollett, J. R. (1997). Educational law: A requisite course for preservice and inservice teacher education programs. Journal of Teacher Education, 48(2), 129-135.

İlbuğa, E. U. (2010). Medya pedagojisi öğretmen eğitiminde. İstanbul Üniversitesi Iletişim Fakültesi Dergisi, 1(38), 65-74.

Kara, T. (2011). Görsel medyanın aile bireyleri üzerindeki etkisi üzerine bir araştırma. TÜIKK Uzmanlık Tezi. Manisa: Türkiye İstatistik Kurumu.

Kaziaj, E. (2016) 'The adult gaze': Exploring the representation of children in television news in Albania. Journal of Children and Media, 10(4), 395-412.

Keane, J. (2010). Medya ve demokrasi. (H. Şahin, Çev.). İstanbul: Ayrıntı Yayınları.

Kuş, Z., Karatekin, K., Öztürk, D., \& Elvan, Ö. (2016). When the child gets in the news? A case study on the national written media in Turkey, Educational Media International, 53(2), 118-138.

Lansdown, G., \& Karkara, R. (2006). The view of children rights. Lancet, 367, 690-692. 
Levent, F. (2011). Üstün yetenekli çocukların hakları. İstanbul: Çocuk Vakfı Yayınları.

Levent, F. (2013). Günlük gazetelerde üstün yetenekli çocuklara yönelik haberlerin incelenmesi. İçinde: 1 . Türkiye Çocuk ve Medya Kongresi Bildiriler Kitabl/1, (ss.321-334). İstanbul: Çocuk Vakfi Yayınları.

Livingstone, S., \& Bulger, M. E. (2013). A global agenda for children's rights in the digital age. Italy: UNICEF Office of Research. (Erişim: 10.12.2017), http://eprints.lse.ac.uk/54276/1/livingstone_global_agen da_childrens_digital_2014_author.pdf

Mercin, L. (2010). 1992'den günümüze yaz olimpiyat oyunları afişlerinin incelenmesi. Dicle Üniversitesi Sosyal Bilimler Enstitüsü Elektronik Dergisi, 2(4), 1-15.

Okçu, D. (2007). Eğitim hakkı ve tarihsel gelişimi. Yüzüncü Yll Üniversitesi Eğitim Fakültesi Dergisi 4(1), 45-59.

Özden, Y. (2005). Eğitim ve okul yöneticiliği. Ankara: PegemA Yayıncilik.

Pavlik, J. V. (2013). Yeni medya ve gazetecilik. Ankara: Phoenix Yayınevi.

Rivers, W. L. (1982). The other government: power and the Washington media. New York: Universe Books.

Savaş, G. (2006). Kitle iletişim araçlarına eleştirel bir yaklaşım. International Journal of Human Sciences, 1(1), 1-5.

Şirin, M. R., Oktay, N., \& Altun, A. (2013). I. Türkiye Çocuk ve Medya Stratejisi ve Uygulama Planı 20142018. İstanbul: Çocuk Vakfi Yayınları.

T.C. İçişleri Bakanlığı (2017). Okul Servis Araçları Yönetmeliği. (Erişim: 10.01.2018), http://www.resmigazete.gov.tr/eskiler/2017/10/2017102 5-2.htm

T.C. Milli Eğitim Bakanlığı (2007). Okul Servis Araçları Hizmet Yönetmeliği. (Erişim: 10.12.2017), http://mevzuat.meb.gov.tr/html/26627_0.html

Turam, E. (1994). Medyanın siyasi hayata etkileri. İstanbul: İrfan Yayınc1lik.

UNICEF (2007). Çocuk haklart ve gazetecilik uygulamaları: hak temelli perspektif. Dublin: UNICEF Dublin Teknoloji Enstitüsü. (Erişim: 10.12.2017), http://www.unicef.org.tr/files/bilgimerkezi/doc/Cocuk\% 20Haklari\%20ve\%20Gazetecilik.pdf

UNICEF (2012). Children's rights and business principles. (Erişim: 10.12 .2017 ), https://www.unicef.org/ indonesia/CHILD_RIGHTS_AND_BUSINESS_PRINC IPLES.pdf

Yıldırım, A., \& Şimşek, H. (2013). Sosyal bilimlerde nitel araştırma yöntemleri. Ankara: Seçkin Yayıncılık.

Yılmaz, E. (1996). Kütüphanecilikte halkla ilișkiler ve kitle iletişim araçları. Yüksek Lisans Tezi. Ankara: Hacettepe Üniversitesi. 